\title{
Relationship between cysteinyl leukotrienes and nitric oxide in the pathogenesis of asthma in obesity
}

Michael J. Coffey*, Barbara Torretti and Alan Baptist

*Correspondence: coffeym@umich.edu

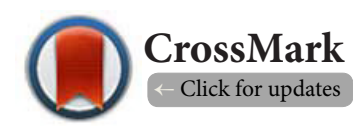

Department of Internal Medicine, Division of Pulmonary and Critical Care Medicine, Allergy and Immunology, University of Michigan Medical Center, Ann Arbor, Michigan, 48109, USA.

\begin{abstract}
Background: Obesity has become a lot more prevalent recently, and its involvement with pathogenesis of asthma is frequently investigated.

Aims: We hypothesize that altered plasma adipoikines and exhaled nitric oxide (NO) levels in obese subjects upregulate inflammation in asthmatics. We examined the hypothesis that the inflammatory mediators, cysteinyl leukotrienes (cys-LT) which are regulated by leptin and NO, play a role in the pathogenesis of airway inflammation in obese asthmatics.

Methods: We studied asthmatics $(\mathrm{n}=59)$ and non-asthmatics $(\mathrm{n}=58)$, both obese and non-obese, and further analyzed by gender. We examined plasma leptin, and fractional exhaled nitric oxide (FeNO), in obese and non-obese asthmatics and non-asthmatics. In addition, we measured urinary cys-LT levels in these subjects.

Results: Plasma leptin was increased in asthmatics compared to non-asthmatics (34.5 \pm 31 vs. $27.0 \pm 26$, $\mathrm{p}=0.038)$, specifically in obese female asthmatics compared to obese male asthmatics (65.1 \pm 22.5 vs. $26.2 \pm 15.9$ $\mathrm{ng} / \mathrm{ml}, \mathrm{p}=0.01)$. FeNO were decreased in obese compared to non-obese asthmatics (17.8 \pm 9.3 vs. 29.5 \pm 22.4 , $\mathrm{p}=0.04)$, an effect that was most noted in female asthmatics. Urinary cys-LT levels were elevated in female asthmatic (7.2 \pm 2.9 vs. $5.0 \pm 1.8, \mathrm{p}=0.002)$, especially in older heavier subjects. The ratio of urinary cys-LT to FeNO was elevated in obese female asthmatics.

Conclusions: Pro-inflammatory leptin and anti-inflammatory NO are altered in obese asthmatics. These mediators may regulate cys-LT. The group of subjects with elevated cys-LT/FeNO ratios may be a target for selective therapy.
\end{abstract}

Keywords: Obesity, leptin, nitric oxide, eicosanoid, airway

\section{Introduction}

There has been a significant increase in the prevalence in obesity in the US, from $18 \%$ in the ' 80 's to approximately 35 $\%$ in 2010 [1,2]. Over the same time frame, there has been an increase in the prevalence of asthma from 30.7 to 53.8 per thousand population. A positive independent association between obesity and the incidence of adult-onset asthma was noted in a prospective epidemiologic study [3]. National Health and Nutrition Examination Survey data, demonstrated an independent association between obesity and asthma, both atopic and non-atopic [4]. Obesity is independently associated with increased airway hyper reactivity [5]. Furthermore, weight loss improves airway narrowing and bronchial hyper reactivity [6]. Obesity is disproportionately common among patients with asthma $[7,8]$.

Leukotrienes (LT) are derived from arachidonic acid metabolism and known to play an important role in airway inflammation and the development of asthma [9]. The 5-lipoxygenase enzyme acts on the arachidonic acid pathway producing $\mathrm{LTB}_{4^{\prime}}$ and cys-LT $\left(\mathrm{LT} \mathrm{C}_{4}, \mathrm{D}_{4}\right.$ and $\left.\mathrm{E}_{4}\right)$. Cys- $\mathrm{LT}$ and $\mathrm{LTB}_{4}$ are released by granulocytes (neutrophils, eosinophils) as well as mast cells, peripheral blood monocytes and macrophages, which are involved in the pathogenesis of airway obstruction [9]. LT synthesis is increased in peripheral blood leukocytes $[10,11]$ airway macrophages and eosinophils [12] from asthmatics compared to healthy controls. Asthma in obese subjects often manifests steroid resistance and is difficult to manage [13]. Other investigators have demonstrated an association between body mass index (BMI) and 
urine cys-LT in obese asthmatics [14]. Obese subjects with asthma, have demonstrated reduced responsiveness to inhaled corticosteroids and display a greater improvement to the LT modifier, montelukast, compared to non-obese asthmatics [15]. By deduction, LTs may play a larger role in mechanisms of asthma in obese subjects compared to non-obese patients [15].

Obesity is a pro-inflammatory state, with adipocytes releasing peripheral blood cytokines such as tumor necrosis factor- $\alpha$, interleukin- $1 \beta$, and interleukin- 6 , and many other classical mediators [16]. Adipose tissue also elaborates a number of adipokines, hormones that are structurally similar to cytokines with both pro- and anti-inflammatory properties. Leptin, is one such adipokine, a $16 \mathrm{kD}$ protein involved in the regulation of food intake and energy balance [17]. Plasma leptin levels correlate with total body fat stores, with an elevation in obesity and a reduction following weight loss. Leptin is a pro-inflammatory cytokine that upregulates both Th1 cytokines [18] and LT [19,20].

Leptin may promote pulmonary inflammation and bronchoconstriction as shown in murine models of obesity asthmatics $[21,22]$. However, there are inconsistent data supporting a role for leptin in the pathogenesis of asthma in humans, independent of BMI [23]. We have preliminary data that plasma leptin levels are increased in obese asthmatics [24]. Plasma leptin also tended to be increased in asthmatics compared to non-asthmatics, irrespective of obesity.

FeNO measurements provide information on underlying eosinophilic airway inflammation, and current evidence suggests a role in identifying the phenotype of corticosteroid responsiveness. However, FeNO does not provide information about airway inflammation characterized by neutrophilic infiltration, which can be seen in severe asthma. Others have shown that there is a negative correlation between BMI and FeNO in asthma [25]. Investigators have demonstrated increased asymmetric di-methyl arginine compared to Larginine in obesity [26]. This uncouples NO synthase leading to lowered FeNO. Late-onset asthmatics display higher median plasma asymmetric di-methyl arginine levels (and lower median plasma L-arginine levels) compared with early onset asthma. Log L-arginine/asymmetric di-methyl arginine and FeNO inversely correlated with BMI.

We and others have shown that both endogenous and exogenous nitric oxide (NO) is anti-inflammatory and suppresses 5-lipoxygenase activity and LT synthesis [27-30]. Therefore, reduced FeNO may lead to excess cys-LT synthesis in the airways of asthmatics with obesity and lead to worsening of pulmonary function in this population. There is an increased predictive value of using combinations of biomarkers to predict therapeutic responses. A recent study demonstrated that a high ratio of urinary $\mathrm{LTE}_{4}$ to FeNO was associated with increased responsiveness to LT receptor antagonists compared to inhaled corticosteroids [31]. This group of subjects with comparatively higher cys-LT / FeNO ratio tended to have less allergic, more neutrophil driven airway disease as seen in rhinovirus infections, and smokers [32,33]. We explored the relationship of these two biomarkers in subjects with mild to moderate asthma with obesity compared to non-obese.

\section{Methods \\ Recruitment}

Recruited subjects, with or without asthma, were 18-65 yr. old, both male and female, and representative of the ethnicity and race distribution of the community's population. Fully informed written consent was obtained from each subject prior to entry into the study. All procedures were approved by the Institutional Review Board of the University of Michigan. $\mathrm{BMI}$ calculations were determined by dividing the weight by the square of the height $\left(\mathrm{kg} / \mathrm{m}^{2}\right)$. Subjects who met inclusion criteria were enrolled consecutively and studied based on $\mathrm{BMI}$, 1) normal BMI $\left(20-24.9 \mathrm{~kg} / \mathrm{m}^{2}\right)$ and 2) obese BMI $\left(>30 \mathrm{~kg} / \mathrm{m}^{2}\right)$ to optimize potential differences.

Stable asthmatics without exacerbations for 2 months were included. The diagnosis of asthma was based on history, physical exam, and pulmonary function testing. Pulmonary testing included forced expiratory volume in one second $\left(F V_{1}\right)$ measurements were performed pre-bronchodilator on all asthmatic patients. Patients with mild to moderate persistent asthma (Step 1-3) were studied, including subjects on inhaled corticosteroids $[34,35]$. Vital signs including the BMI values were determined in all subjects on the day of the study.

Exclusion criteria include current smokers within the past 6 months and previous smokers $>20$ pack years, intercurrent infection, and treatment with LT-modifier drugs, cyclooxygenase-1 inhibitors including aspirin, and oral corticosteroids. Subjects with aspirin exacerbated respiratory disease were excluded because of their tendency to display excess cys-LT synthesis at baseline [36].

\section{Blood}

Plasma leptin levels were determined spectrophotometrically using commercially-available colorimetric enzyme immunoassay kits (Millipore, MA USA) according to the manufacturer's instructions [37]. The coefficient of variation for duplicate samples was $3.7 \%$ and the lower limit of detection was 0.5 $\mathrm{ng} / \mathrm{ml}$. Blood samples were drawn from each patient at the same time of the day, in the morning, and when fasting.

\section{Exhaled breath}

Subjects were asked to perform two FeNO measurements using the NIOX MINO Airway Inflammation Monitor (NIOX MINO; Aerocrine AB, Solana, Sweden). The NIOX MINO required the subjects to exhale at a constant pressure between 10 and $20 \mathrm{cmH}_{2} \mathrm{O}$ and adjusts flow to the American Thoracic Society recommended flow rate of $50+/-5 \mathrm{ml} / \mathrm{s}$ [38]. The NIOX MINO has previously shown good correlation with traditional NO analyzers [39].

\section{Urine}

Urine was collected (spot) and kept in a refrigerator until 
aliquoting $(10 \mathrm{ml})$ and freezing $\left(-80^{\circ} \mathrm{C}\right)$. Urine cysteinyl leukotriene was analyzed by enzyme-linked immunosorbent assay with the detection limit $<10 \mathrm{ng} / \mathrm{l}$ and the inter-assay variation $<12 \%$ [40]. Urine cys-LT levels are presented as $p g /$ $\mathrm{mg}$ creatinine. These samples were run using the kits from Cayman Chemicals, Ann Arbor.

\section{Statistics}

Mean and standard deviations for normally distributed data were calculated and differences between groups determined by the Student $t$ test. For skewed data Mann-Whitney tests were utilized. For the evaluation of possible associations between each study variable (dependent) and BMI (independent), linear regression was performed. We log transformed the data since it was not normally distributed. This log transformation resulted in normalization of the data.

Correlations and partial correlations were performed using Pearson's coefficient. Multivariable regression analysis was performed for leptin, FeNO and urine cys-LT levels, adjusting for age, gender and asthma. We evaluated the association with $\mathrm{BMI}$ categories as well as BMI as a continuous variable.

Multiple comparison of study variables among the four groups were performed with one way analysis of variance (ANOVA) using a Bonferroni correction. The data were log transformed prior to ANOVA. P values $<0.05$ were considered statistically significant. All statistics were performed on IBM SPSS version 21 statistical software.

\section{Results}

We set out to study four groups of subjects: obese asthmatics, non-obese asthmatics; obese non-asthmatics and non-obese non-asthmatics. The total number of subjects studied was 117. By design the BMI of the control and obese subjects were recruited to obtain optimal separation of the groups (Table 1). There was no significant difference in $\mathrm{FEV}$, between obese and non-obese asthmatics ( $82.6 \pm 14.3$ vs. $91.0 \pm 14.9 \%$ predicted, $\mathrm{p}=0.07$ ).

The gender breakdown was $65 \%$ female, ( $35 \%$ male). No significant difference occurred in BMI between the genders, obese ( $39.3 \pm 5.9$ vs. $38.6 \pm 6.5$ years male:female), or non-obese (23.0 \pm 1.6 vs. $22.8 \pm 1.8)$.

The recruitment age in the subjects, asthma vs. non-asthma, wasn't significantly different; (Table 1). Males and females displayed no difference in age. Obese subjects were generally older, displaying an age-related increase in fat mass (obese $43.4 \pm 12.4$ vs. non-obese 30.8 vs. $\pm 11.9, p=0.0001$ ). Obese asthmatics were on average older than non-obese asthmatics $(44.0 \pm 10.3$ vs. $29.9 \pm 9.8$ years, $p=0.0001)$.

Co-morbidities: There are a number of co-morbidities that contribute to exacerbations of asthma. Thirteen of the obese subjects had a diagnosis of obstructive sleep apnea, compared to none in the non-obese population. These were evenly divided among asthmatics and non-asthmatics (8/59 vs. 5/58 subjects). Gastro-esophageal reflux disease was more
Table 1. Demographics of the study population of obese, non-obese, asthmatic and non-asthmatic subjects.

\begin{tabular}{|l|c|c|l|}
\hline & Asthma & Non Asthma & p \\
\hline $\mathbf{n}$ & 59 & 58 & $=0.95$ \\
\hline BMI & $32.0 \pm 9.3$ & $29.7 \pm 8.3$ & $=0.98$ \\
\hline Age & $37.3 \pm 12.2$ & $36.8 \pm 14.9$ & \\
\hline M:F & $18: 41$ & $22: 36$ & \\
\hline Subgroups & & & \\
\hline & Obese / Non-obese & Obese / Non-obese & \\
\hline $\mathbf{n}$ & $30 / 29$ & $28 / 30$ & \\
\hline BMI & $38.9 \pm 6.1 / 22.8 \pm 1.7$ & $37.7 \pm 5.4 / 22.9 \pm 1.7$ & \\
\hline Age & $44.0 \pm 10.3 / 29.9 \pm 9.8$ & $42.7 \pm 13.6 / 31.5 \pm 11.6$ & \\
\hline M:F & $9: 21 / 9: 20$ & $7: 21 / 15: 15$ & \\
\hline
\end{tabular}

Notes: BMI, body mass index; M/F, male / female. Data presented as mean $\pm \mathrm{SD}$.

common in obese subjects than non-obese (13/58 vs. 2/59 subjects). Gastro-esophageal reflux disease was also more common in asthmatics than in non-asthmatics (11/59 vs. $4 / 58$ subjects).

\section{Leptin levels}

As expected, fasting plasma leptin levels were higher in obese subjects than non-obese subjects ( $51.4 \pm 25.7$ vs. $9.4 \pm 8.6 \mathrm{ng} / \mathrm{ml}$, $\mathrm{p}<0.0001)$. There was a significant increase in leptin levels in asthmatics compared to non-asthmatics ( $34.5 \pm 31$ vs. $27.0 \pm 26$, $p=0.038$ ). Mean leptin levels were higher in females than in males ( $39.9 \pm 29.0$ vs. $12.5 \pm 15.8 \mathrm{ng} / \mathrm{ml}, \mathrm{p}<0.0001)$. Female asthmatics had higher leptin levels than males with asthma $(42.9 \pm 31.0$ compared to $17.6 \pm 18.8 \mathrm{ng} / \mathrm{ml}, \mathrm{p}=0.004)$ (Figure 1). Leptin levels were higher in obese female asthmatics compared to obese male asthmatics $(65.1 \pm 22.5$ vs. $26.2 \pm 15.9 \mathrm{ng} /$ $\mathrm{ml}, \mathrm{p}=0.01$ ) (Figure 1 and Table 3 ).

Leptin's correlation with weight was positive at 0.8 , which was significant $(p<0.0001)$. When adjusted for asthma it was $0.8(p<0.0001)$. The correlation of leptin with asthma is -0.25 $(p=0.07)$. When adjusted for BMI the correlation was -0.13 $(p=0.36)$. Multivariable linear regression analysis demonstrated a positive correlation between leptin and weight ( 0.81 , $p<0.001)$. There was also a positive correlation between leptin and the female gender $(0.44, p<0.001)$.

Using ANOVA, leptin was significantly different between the four groups: obese asthmatics, non-asthma non-obese, asthma non-obese and non-asthma obese. Obese asthmatics had significantly higher levels than obese non-asthmatics $(p<0.0001)$ (Figure 2).

\section{Urine Cys-LT levels}

There was no significant difference in urine cys-LT levels between asthmatics and non-asthmatics $(6.7 \pm 2.9$ vs. $6.5 \pm 3.3$, $\mathrm{p}=0.8$ ). Likewise, there was no difference between obese and non-obese subjects $(6.9 \pm 3.2$ vs. $6.3 \pm 3.0, p=0.26)$. Urine cys-LT levels were no different in obese asthma compared non-obese asthmatics ( $7.2 \pm 3.2$ vs. $6.3 \pm 2.6, p=0.2)$, but females trended to 

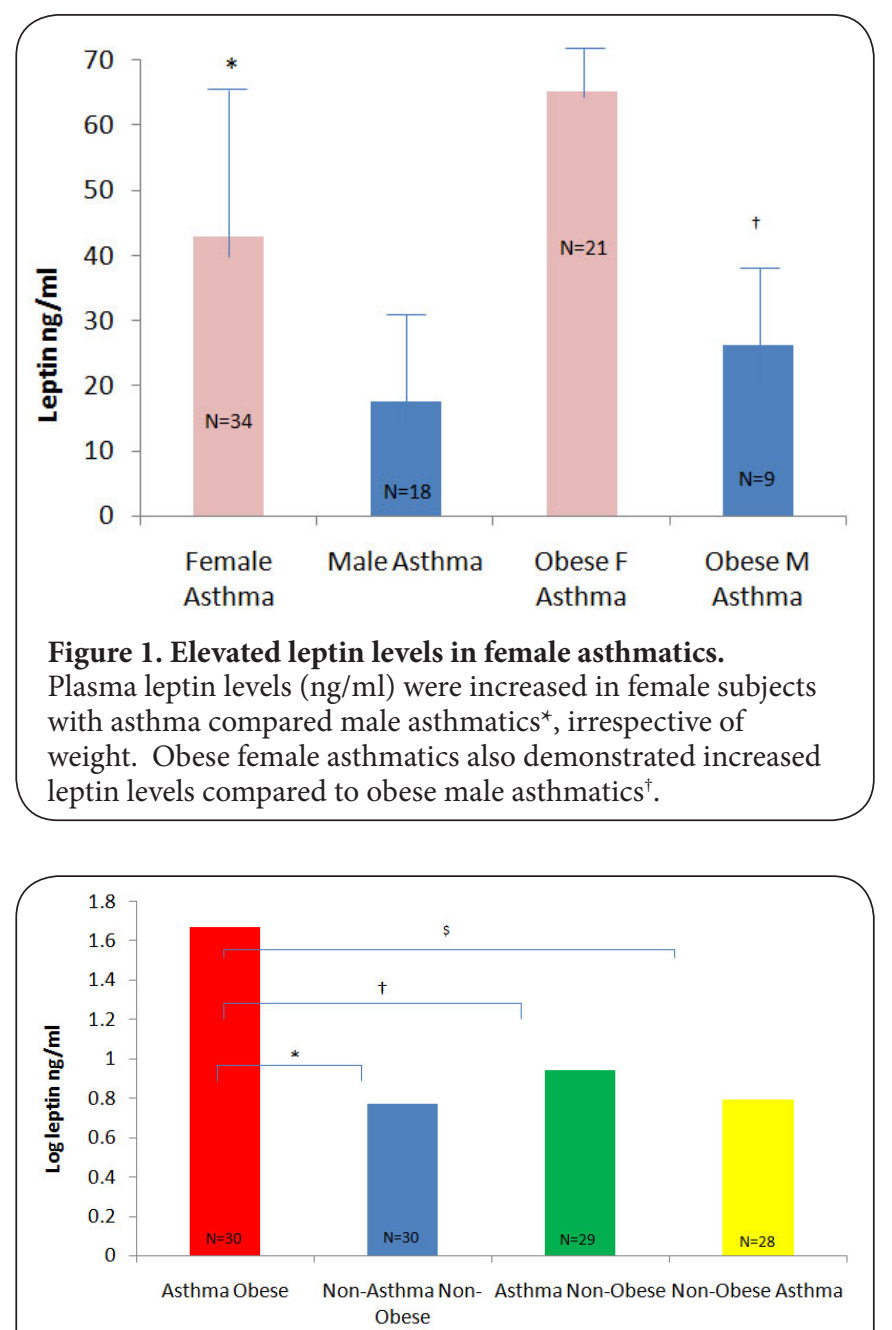

Figure 2. Increased leptin levels in obese asthmatics compared to non-obese asthmatics and non-asthmatics. Plasma leptin levels log mean transformed $(\mathrm{ng} / \mathrm{ml})$ in subjects with asthma obesity (AO), non-asthma non-obesity (NANO), asthma non-obesity (ANO), non-asthma obesity (NAO). AO had significantly higher leptin levels (ANOVA $\mathrm{p}<0.05$ ), compared with $\mathrm{NANO},{ }^{*} \mathrm{ANO}^{\dagger}$ and $\mathrm{NOA}^{\$}$.

Table 2. Mediator levels in obese, non-obese, asthmatic and nonasthmatic subjects.

\begin{tabular}{|c|c|c|c|c|c|c|}
\hline & \multicolumn{2}{|c|}{ Asthma } & $\mathbf{P}$ & \multicolumn{2}{|c|}{ Non Asthma } & p \\
\hline $\begin{array}{l}\text { Leptin } \\
\mathrm{ng} / \mathrm{ml}\end{array}$ & $\begin{array}{c}55.4 \pm \\
26.9\end{array}$ & $\begin{array}{c}24.2 \pm \\
12.9\end{array}$ & $P=0.0001$ & $\begin{array}{c}46.5 \pm \\
24.2\end{array}$ & $\begin{array}{c}8.9 \pm \\
8.8\end{array}$ & $P=0.0001$ \\
\hline $\begin{array}{l}\text { UCys- } \\
\text { LT/FeNO }\end{array}$ & $\begin{array}{c}0.50 \pm \\
0.4\end{array}$ & $\begin{array}{c}0.30 \pm \\
0.21\end{array}$ & $\mathrm{P}=0.11$ & $\begin{array}{c}0.44 \pm \\
0.21\end{array}$ & $\begin{array}{c}0.42 \pm \\
0.3\end{array}$ & $P=0.6$ \\
\hline
\end{tabular}

Notes: U Cys-LT/FeNO, ratio urinary cysteinyl leukotrienes to fractional exhaled nitric oxide. Data presented as mean $\pm \mathrm{SD}$.

have higher urine cys-LT levels than males (7.3 \pm 4.4 vs. $5.9 \pm 3.1$, $\mathrm{p}=0.07$ ). Female asthmatics had significantly higher urine cys-

Table 3. Role of gender in mediator levelsin obese, non-obese, asthmatic and non-asthmatic subjects.

\begin{tabular}{|c|c|c|c|c|c|c|c|}
\hline & & \multicolumn{2}{|c|}{ Asthma } & \multirow[t]{2}{*}{ p } & \multicolumn{2}{|c|}{ Non-asthma } & \multirow[t]{2}{*}{$\mathbf{p}$} \\
\hline & & Female & Male & & Female & Male & \\
\hline \multirow[t]{2}{*}{$\begin{array}{l}\text { Leptin } \\
\mathrm{ng} / \mathrm{ml}\end{array}$} & $\begin{array}{l}\text { Non- } \\
\text { obese }\end{array}$ & $\begin{array}{l}14.3 \pm \\
8.0\end{array}$ & $\begin{array}{l}26.2 \pm \\
19.4\end{array}$ & $\mathrm{P}=0.6$ & $\begin{array}{l}14.6 \pm \\
9.4\end{array}$ & $\begin{array}{l}3.3 \pm \\
1.3\end{array}$ & $P=0.002$ \\
\hline & Obese & $\begin{array}{l}65.1 \pm \\
22.5\end{array}$ & $\begin{array}{l}26.2 \pm \\
15.9\end{array}$ & $P=0.01$ & $\begin{array}{l}53.8 \pm \\
22.3\end{array}$ & $\begin{array}{l}28.1 \pm \\
19.4\end{array}$ & $\mathrm{P}=0.07$ \\
\hline \multirow[t]{2}{*}{$\begin{array}{l}\text { U Cys-LT } \\
\text { / FeNO }\end{array}$} & $\begin{array}{l}\text { Non- } \\
\text { obese }\end{array}$ & $\begin{array}{l}0.32 \pm \\
0.24\end{array}$ & $\begin{array}{l}0.27 \pm \\
0.18\end{array}$ & $\mathrm{P}=0.7$ & $\begin{array}{l}0.51 \pm \\
0.34\end{array}$ & $\begin{array}{l}0.34 \pm \\
0.24\end{array}$ & $P=0.06$ \\
\hline & Obese & $\begin{array}{l}0.57 \pm \\
0.49\end{array}$ & $\begin{array}{l}0.19 \pm \\
0.08\end{array}$ & $\mathrm{p}=0.2$ & $\begin{array}{l}0.48 \pm \\
0.22\end{array}$ & $\begin{array}{l}0.34 \pm \\
0.19\end{array}$ & $P=0.03$ \\
\hline
\end{tabular}

Notes: U Cys-LT/FeNO, ratio urinary cysteinyl leukotrienes to fractional exhaled nitric oxide. Data presented as mean \pm SD.

LT levels than male asthmatics (7.2 \pm 2.9 vs. $5.0 \pm 1.8, p=0.002)$.

Urinary cys-LT correlation with leptin was 0.17 , nonsignificant, with $p=0.08$. There was no significant correlation of urinary cys-LT with FeNO $(0.09, p=0.38)$. The strongest correlation of urinary cys-LT was with age at 0.24 , which was significant $(p=0.012)$. Controlling for $B M I$, the correlation with age was $0.202, p=0.037$. Controlling for leptin was $0.21, p=0.03$.

\section{FeNO}

FeNO overall displayed no difference in asthmatics compared to non-asthmatics ( $23.5 \pm 17.8$ vs. $20.4 \pm 12.4, p=0.4)$. Interestingly, FeNO levels were decreased in obese compared to nonobese ( $18.9 \pm 9.8$ vs. $24.6 \pm 18.6, p=0.05)$ subjects, irrespective of whether they had asthma. FeNO was also significantly reduced in obese asthmatics compared to non-obese asthmatics ( $17.8 \pm 9.3$ vs. $29.5 \pm 22.4, p=0.04$ ) (Table 2). There was no significant difference in FeNO in females compared to males (19.3 \pm 13.0 vs. $26.5 \pm 17.7, p=0.13)$, so the lack of elevation of FeNO in asthmatics compared to non-asthmatics was likely primarily related to obesity.

Linear regression demonstrated that FeNO has a significant negative correlation with BMI at $-0.153(p=0.05)$. FeNO demonstrated a negative correlation with asthma $(-0.175$, $\mathrm{p}=0.036)$ but did not correlate with $\mathrm{FEV}_{1}(0.055, \mathrm{p}=0.345)$. Likewise, FeNO demonstrated a significant negative correlation with the female gender $(-0.23, p=0.01)$. Using multiple linear stepwise regression only asthma and gender (female) had a negative correlation, when the variables: age, gender, $\mathrm{BMI}$ and asthma were considered $(p=0.02)$.

Using ANOVA, FeNO was significantly different between the four groups: obese asthmatics, non-asthma non-obese, asthma non-obese and non-asthma obese. Obese asthmatics had significantly lower FeNO levels than non-obese asthmatics $(p=0.002)$ (Figure 3$)$.

\section{Urine cys-LT/FeNO ratio} The high ratio of urine cys-LT to FeNO has been demonstrated 


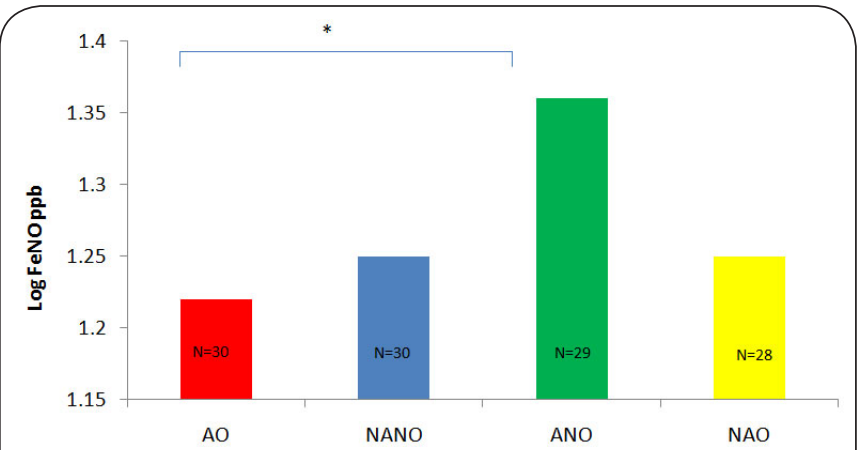

Figure 3. Reduced FeNO concentrations in obese asthmatics. $\mathrm{FeNO}$ (ppb) concentrations were measured in subjects with asthma obesity (AO), non-asthma non-obesity (NANO), asthma non-obesity (ANO), non-asthma obesity (NAO). AO had significantly lower FeNO levels (ANOVA p <0.002) compared with $\mathrm{ANO}^{*}$.

as a marker of subjects who respond preferentially to LT modifier therapy $[32,41]$. We calculated the urine cys-LT/FeNO ratio in our subjects to help characterize the usefulness of this marker in the obese asthma population. There was no significant difference in the urine cys-LT/FeNO ratio between asthmatics and non-asthmatics ( $0.4 \pm 0.37$ vs. $0.43 \pm 0.26$, $\mathrm{p}=0.7$ ) (Table 2). However, female asthmatics demonstrated a significant increase in urine cys-LT/FeNO ratio compared to male asthmatics $(0.52 \pm 0.35$ vs. $0.25 \pm 0.16, p=0.012)$ (Figure 4). Obese female asthmatics had an increased urine cys-LT/FeNO ratio compared to non-obese male asthma $(0.57 \pm 0.24 \mathrm{vs}$. $0.27 \pm 0.03, p=0.04)$.

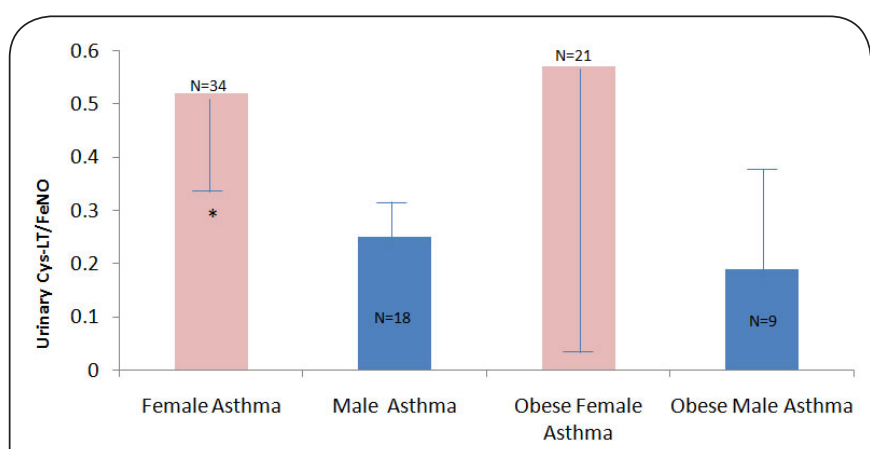

Figure 4. Urinary cys-LT/FeNO ratio in obese and non-obese asthmatics.

Urinary cys-LT/FeNO ratio was higher in female asthmatics compared to male subjects with asthma*. There was a trend towards an increased ratio in obese female asthmatics, but it was not significant.

Correlation of urine cys-LT/FeNO with gender was $0.28, p=0.004$, BMI 0.23, p=0.02, leptin 0.24, $p=0.014$, asthma $0.04, p=0.66$, and age $0.1, p=0.3$. Correlation of urine cys-LT/FeNO with $\mathrm{BMI}$ when controlling for gender was still significant $(0.21$, $\mathrm{p}=0.04)$. The correlation of cys-LT/FeNO with gender when controlling for $\mathrm{BMI} 0.3, \mathrm{p}=0.01$.

Linear regression demonstrated urine cys-LT/FeNO ratio had a correlation with gender $0.28, \mathrm{p}=0.002, \mathrm{BMI} 0.23$ (continuous variable), $p=0.009$, weight -0.13 (categorical variable obese or non-obese), $p=0.08$, and leptin $0.24, p=0.007$. Using multiple linear stepwise regression only gender (female) and BMI had a positive correlation, when the variables: age, gender, leptin, $\mathrm{BMI}$ and asthma were considered $(\mathrm{p}=0.002)$.

\section{Discussion}

The findings of this study are: 1) plasma leptin levels are increased in asthmatics compared to non-asthmatics, particularly in obese asthmatics compared to obese non-asthmatics. This was mainly accounted for by higher leptin levels in females, and especially obese female asthmatics. 2) Urine cys-LT levels were elevated in female asthmatics and were increased in older heavier subjects. 3) FeNO levels were significantly reduced in obese compared to non-obese asthmatics. There was also a negative correlation between females and FeNO. 4) The urine cys-LT/FeNO ratio was higher in obese female asthmatics.

The finding of the association between leptin and asthma, and specifically in obese female asthmatics corroborates data from a previous study from our laboratory [24]. Leptin has been noted to be a pro-inflammatory adipokine driving the immune system towards a predominant Th1 phenotype [42]. Leptin may also have an impact in the airway milieu in asthmatics with obesity. It may increase pro-inflammatory phenotype in macrophages [43], augmenting the response to LPS. Leptin deficient mice display reduced LT synthesis, and exogenous leptin augments LT production in macrophages from these animals [19]. Obesity has also been associated with an alteration in adipokines that predispose to neutrophilic inflammation [44]. Recently, it has also been shown that leptin may also affect the airway diameter through non-inflammatory pathways by inhibiting the cholinergic pathway [22]. Population studies have shown no association between leptin and asthma, but they studied non-fasting subjects, smokers, variables that can affect leptin levels, and may explain their different conclusions [45].

The reduced bronchial responsiveness to inhaled corticosteroids in patient with obesity, with a relatively stable response to montelukast, has been previously described [15]. Other investigators have demonstrated an association between BMI and urine cys-LT in obese asthmatics [14]. Obese patients displayed significantly higher values of LTE 4 creatinine in urine compared to subjects who were pre-obese and in the normal range. The only significant associations were those between $\mathrm{BMI}$ and $\mathrm{LTE}_{\text {/ creatinine in urine, using }}$ a linear regression model. Log leptin and log adiponectin presented positive and negative associations, respectively with $\mathrm{LTE}_{4}$ /creatinine in urine, using the same model. However, urine cys-LT measurements in our study were very variable and not sensitive enough to detect significant difference between groups. Notably, in Giouleka's study there was no association between $\mathrm{BMI}$ and exhaled breath condensate $\mathrm{LTE}_{4}$ levels [14]. This was because of the increased variability 
noted with exhaled breath condensate samples.

In our cohort, subjects with the older obese women phenotype trended to have increased leptin and urine cys-LT levels with worse pulmonary function. Obese female asthmatics had higher leptin levels than obese male asthmatics. Recently, investigators have demonstrated that $\mathrm{BMI}$ was associated with the incidence of asthma in women but not in men [46]. Furthermore, adult onset non-atopic asthma has become the most common type of asthma in women [47]. Investigators have demonstrated that both testosterone (negative) and estrogen (positive) were associated with alterations in adipokines, specifically leptin levels [48]. The increase in BMI with age may have offset the effect of any change in estrogen / testosterone levels on adipokine levels as subjects increased in years.

In our study FeNO was not significantly elevated in asthmatics compared to non-asthmatics including both obese and non-obese subjects. This was explained in part by the role of obesity. FeNO was reduced in obese compared to non-obese subjects. It was also decreased in obese asthmatics compared to non-obese asthmatics. Reduced arginine / asymmetric dimethyl arginine ratio in obesity may explain this phenomenon [26]. The negative correlation between FeNO and the female gender (who made up $65 \%$ of subjects) compared to males may also be influencing this finding. Although FeNO levels did not correlate with urine cys-LT levels, the reduction in FeNO levels in obese subjects may contribute to the increased cys-LT levels seen in these subjects in urine measurements [14] as well as in exhaled breath condensate [24].

Urine $\mathrm{LTE}_{4} / \mathrm{FeNO}$ ratio has been utilized as a marker for subjects that respond preferentially to LT modifier drugs compared to inhaled corticosteroids in the management of children with asthma [32]. These subjects tended to have less IgE sensitivity, lower eosinophil counts and less responsiveness to inhaled corticosteroids. Likewise subjects with exercise-induced asthma with higher urine $\mathrm{LTE}_{4} / \mathrm{FeNO}$ ratios tended to respond better to LT receptor antagonists than to inhaled corticosteroids [41]. Urine cys-LT/FeNO ratio in our study was higher in obese female asthmatics. This may identify a subgroup of obese female asthmatics who will respond better to LT modifiers.

We documented comorbidities of obstructive sleep apnea and gastro-esophageal reflux disease in asthmatics and non-asthmatics. Poorly controlled obstructive sleep apnea has been shown to worsen asthma control, in part through increased release of pro-inflammatory mediators during episodes of hypoxia and disrupted sleep [49]. Nocturnal gastro-esophageal reflux disease may exacerbate asthma with aspiration of acid, during inhalation against a closed airway, following episodes of upper airway obstruction. Like obstructive sleep apnea, the incidence of gastro-esophageal reflux disease is also increased in obese subjects and may exacerbate airway disease after eating. Gastro-esophageal reflux disease can result in reflex bronchospasm from ir- ritation of the esophagus or directly spilling into the airway with gross reflux. Both obstructive sleep apnea and gastroesophageal reflux disease were more common in obese than non-obese subjects in our study. Furthermore, in our cohort gastro-esophageal reflux disease was more prevalent in the asthmatic than in the non-asthmatic group.

There are a number of potential limitations with this study. It is a relatively small study number wise, examining the role of obesity in the pathogenesis of asthma. Furthermore, it is an observational study, with no interventions. Although the diagnosis of asthma was made by a physician with history, physical examination and spirometry, methacholine challenge testing was not performed. Despite these issues, the study has a number of strengths. In recruiting subjects, there was good characterization and separation of subjects between the control group and obese subject group. In addition, the asthmatics were well characterized compared to the non-asthmatics with spirometry, and asthma control test questionnaires. Furthermore, the significance of the study was improved since we studied predominantly moderate persistent asthmatics with many on inhaled corticosteroid therapy. None of the asthmatics were on LT modifier medications.

In summary, We have demonstrated that leptin levels are increased in asthmatics, specifically in obese asthmatics compared to obese non-asthmatics, predominantly in females. FeNO was reduced in obese asthmatics. The combination of increased leptin and lowered FeNO in this population may predispose to elevated urine cys-LT levels, although this was not demonstrated mechanistically in this study. These proinflammatory mediators, increased in obese female asthmatics may promote an asthma phenotype that has become more prevalent and results in difficult to control airway disease.

\section{Competing interests}

The authors declare that they have no competing interests.

Authors' contributions

\begin{tabular}{|l|c|c|c|}
\hline Authors' contributions & MJC & BT & AB \\
\hline Research concept and design & $\checkmark$ & -- & $\checkmark$ \\
\hline Collection and/or assembly of data & $\checkmark$ & $\checkmark$ & $\checkmark$ \\
\hline Data analysis and interpretation & $\checkmark$ & -- & $\checkmark$ \\
\hline Writing the article & $\checkmark$ & -- & $\checkmark$ \\
\hline Critical revision of the article & $\checkmark$ & -- & $\checkmark$ \\
\hline Final approval of article & $\checkmark$ & $\checkmark$ & $\checkmark$ \\
\hline
\end{tabular}

Acknowledgement

This work was supported by a Grant from Merck Investigator Initiated Studies (HUM00037724).

\section{Publication history}

Editor: Donald W. Cockcroft, University of Saskatchewan, Canada. Received: 05-Aug-2017 Final Revised: 16-Sep-2017

Accepted: 16-Oct-2017 Published: 31-Oct-2017 
Coffey, Journal of Allergy and Asthma 2017,

\section{References}

1. Flegal KM, Carroll MD, Kit BK and Ogden CL. Prevalence of obesity and trends in the distribution of body mass index among US adults, 19992010. JAMA. 2012; 307:491-7. | Article | PubMed

2. Fontaine $\mathrm{K}$ et al. Years of life lost due to obesity. JAMA. 2003; 289:187193. | Article | PubMed Abstract | PubMed FullText

3. Camargo, C.J., et al., Prospective study of body mass index, weight change, and risk of adult-onset asthma in women.Arch Intern Med, 1999. 159: p. 2582-2588. | Article

4. Ma J, Xiao $L$ and Knowles SB. Obesity, insulin resistance and the prevalence of atopy and asthma in US adults. Allergy. 2010; 65:1455-63. | Article | PubMed

5. Litonjua AA, Sparrow D, Celedon JC, DeMolles D and Weiss ST. Association of body mass index with the development of methacholine airway hyperresponsiveness in men: the Normative Aging Study. Thorax. 2002; 57:581-5. | Article | PubMed Abstract | PubMed FullText

6. Hakala K, Stenius-Aarniala B and Sovijarvi A. Effects of weight loss on peak flow variability, airways obstruction, and lung volumes in obese patients with asthma. Chest. 2000; 118:1315-21. | Article | PubMed

7. Beuther DA and Sutherland ER. Overweight, obesity, and incident asthma: a meta-analysis of prospective epidemiologic studies. Am J Respir Crit Care Med. 2007; 175:661-6. | Article | PubMed Abstract | PubMed FullText

8. Yigla M, Tov N, Solomonov A, Rubin AH and Harlev D. Difficult-to-control asthma and obstructive sleep apnea. J Asthma. 2003; 40:865-71. | PubMed

9. Henderson WR, Jr. Eicosanoids and lung inflammation. Am Rev Respir Dis. 1987; 135:1176-85. | Article | PubMed

10. Mitsunobu F, Mifune T, Hosaki Y, Ashida K, Tsugeno H, Okamoto M, Harada S, Takata S, Tanizaki Y and Harada M. Enhanced peripheral leukocyte leukotriene production and bronchial hyperresponsiveness in asthmatics. Eur Respir J. 2000; 16:504-8. | Article | PubMed

11. Abrahamsen $\mathrm{O}$, Haas $\mathrm{H}$, Schreiber J and Schlaak M. Differential mediator release from basophils of allergic and non-allergic asthmatic patients after stimulation with anti-IgE and C5a. Clin Exp Allergy. 2001; 31:36878. | Article | PubMed

12. Martin TR. Arachidonic acid metabolism in lung phagocytes. Semin Respir Infect. 1986; 1:89-98. | PubMed

13. Sutherland ER, Goleva E, Strand M, Beuther DA and Leung DY. Body mass and glucocorticoid response in asthma. Am J Respir Crit Care Med. 2008; 178:682-7. | Article | PubMed Abstract | PubMed FullText

14. Giouleka P, Papatheodorou G, Lyberopoulos P, Karakatsani A, Alchanatis $\mathrm{M}$, Roussos $\mathrm{C}$, Papiris $\mathrm{S}$ and Loukides $\mathrm{S}$. Body mass index is associated with leukotriene inflammation in asthmatics. Eur J Clin Invest. 2011; 41:30-8. | Article | PubMed

15. Peters-Golden M, Swern A, Bird SS, Hustad CM, Grant E and Edelman $J M$. Influence of body mass index on the response to asthma controller agents. Eur Respir J. 2006; 27:495-503. | Article | PubMed

16. Ahima R and J. Flier. Leptin. Annu Rev Physiol. 2000; 62:413-37.

17. Friedman JM and Halaas JL. Leptin and the regulation of body weight in mammals. Nature. 1998; 395:763-70. | Article | PubMed

18. Steinman $L$, Conlon $P$, Maki $R$ and Foster $A$. The intricate interplay among body weight, stress, and the immune response to friend or foe. J Clin Invest. 2003; 111:183-5. | Article | PubMed Abstract | PubMed FullText

19. Mancuso P, Gottschalk A, Phare SM, Peters-Golden M, Lukacs NW and Huffnagle GB. Leptin-deficient mice exhibit impaired host defense in Gram-negative pneumonia. J Immunol. 2002; 168:4018-24. | Article | PubMed

20. Mancuso P, Canetti C, Gottschalk A, Tithof PK, Peters-Golden M. Leptin augments alveolar macrophage leukotriene synthesis by increasing phospholipase activity and enhancing group IVC IPLA2 (cPLA2gamma) protein expression. Am J Physiol Lung Cell Mol Physiol. 2004; 287:L497502. | Article | PubMed

21. Shore SA, Schwartzman IN, Mellema MS, Flynt L, Imrich A and Johnston RA. Effect of leptin on allergic airway responses in mice. J Allergy Clin
Immunol. 2005; 115:103-9. | Article | PubMed

22. Arteaga-Solis E, Zee T, Emala CW, Vinson C, Wess J and Karsenty G. Inhibition of leptin regulation of parasympathetic signaling as a cause of extreme body weight-associated asthma. Cell Metab. 2013; 17:35-48. | Article | PubMed Abstract | PubMed FullText

23. Ali Assad $\mathrm{N}$ and Sood $\mathrm{A}$. Leptin, adiponectin and pulmonary diseases. Biochimie. 2012; 94:2180-9. | Article | PubMed Abstract | PubMed FullText

24. Coffey MJ, Torretti B and Mancuso P. Adipokines and Cysteinyl Leukotrienes in the Pathogenesis of Asthma. J Allergy (Cairo). 2015; 2015:157919. | Article | PubMed Abstract | PubMed FullText

25. Wilborn J, Bailie M, Coffey M, Burdick M, Strieter R and Peters-Golden M. Constitutive activation of 5-lipoxygenase in the lungs of patients with idiopathic pulmonary fibrosis. J Clin Invest. 1996; 97:1827-36. | Article | PubMed Abstract | PubMed FullText

26. Holguin F, Comhair SA, Hazen SL, Powers RW, Khatri SS, Bleecker ER, Busse WW, Calhoun WJ, Castro M, Fitzpatrick AM, Gaston B, Israel E, Jarjour NN, Moore WC, Peters SP, Teague WG, Chung KF, Erzurum SC and Wenzel SE. An association between L-arginine/asymmetric dimethyl arginine balance, obesity, and the age of asthma onset phenotype. Am J Respir Crit Care Med. 2013; 187:153-9. | Article | PubMed Abstract | PubMed FullText

27. Brunn G, Hey C, Wessler I and Racke K. Endogenous nitric oxide inhibits leukotriene B4 release from rat alveolar macrophages. Eur J Pharmacol. 1997; 326:53-60. | Article | PubMed

28. Coffey MJ, Phare SM and Peters-Golden M. Prolonged exposure to lipopolysaccharide inhibits macrophage 5-lipoxygenase metabolism via induction of nitric oxide synthesis. J Immunol. 2000; 165:3592-8. | Article | PubMed

29. Coffey MJ, Phare SM and Peters-Golden M. Peroxynitrite-induced nitrotyrosination of proteins is blocked by direct 5-lipoxygenase inhibitor zileuton. J Pharmacol Exp Ther. 2001; 299:198-203. | Article | PubMed

30. Coffey MJ, Phare SM and Peters-Golden M. Interaction between nitric oxide, reactive oxygen intermediates, and peroxynitrite in the regulation of 5-lipoxygenase metabolism. Biochim Biophys Acta. 2002; 1584:81-90. | Article | PubMed

31. Rabinovitch N, Strand M, Stuhlman K and Gelfand EW. Exposure to tobacco smoke increases leukotriene E4-related albuterol usage and response to montelukast. J Allergy Clin Immunol. 2008; 121:1365-71. | Article I PubMed

32. Rabinovitch N, Graber NJ, Chinchilli VM, Sorkness CA, Zeiger RS, Strunk RC, Bacharier LB, Martinez FD and Szefler SJ. Urinary leukotriene E4/ exhaled nitric oxide ratio and montelukast response in childhood asthma. J Allergy Clin Immunol. 2010; 126:545-51 e1-4. | Article | PubMed Abstract | PubMed FullText

33. Tartibi HM and Bahna SL. Clinical and biological markers of asthma control. Expert Rev Clin Immunol. 2014; 10:1453-61. | Article | PubMed

34. Zanconato S, Carraro S, Corradi M, Alinovi R, Pasquale MF, Piacentini G, Zacchello $\mathrm{F}$ and Baraldi E. Leukotrienes and 8-isoprostane in exhaled breath condensate of children with stable and unstable asthma. $J$ Allergy Clin Immunol. 2004; 113:257-63. | Article | PubMed

35. National Asthma Education and Prevention. Practical Guide for the Diagnosis and Management of Asthma. Expert Panel Report 2. US Department of Health and Human Services; Public Health Service. National Institute of Health; National Heart, Lung and Blood Institute, Bethesda, MD. 1997.

36. Sanak M, Pierzchalska M, Bazan-Socha S and Szczeklik A. Enhanced expression of the leukotriene $\mathrm{C}(4)$ synthase due to overactive transcription of an allelic variant associated with aspirin-intolerant asthma. Am J Respir Cell Mol Biol. 2000; 23:290-6. | Article | PubMed

37. Kotidis EV, Koliakos GG, Baltzopoulos VG, loannidis KN, Yovos JG and Papavramidis ST. Serum ghrelin, leptin and adiponectin levels before and after weight loss: comparison of three methods of treatment--a prospective study. Obes Surg. 2006; 16:1425-32. | Article | PubMed

38. ATS/ERS recommendations for standardized procedures for the online 
Coffey, Journal of Allergy and Asthma 2017,

http://www.hoajonline.com/journals/pdf/2054-9873-4-1.pdf

and offline measurement of exhaled lower respiratory nitric oxide and nasal nitric oxide, 2005. Am J Respir Crit Care Med. 2005; 171:912-30. I Article | PubMed

39. Alving K, Janson C and Nordvall L. Performance of a new hand-held device for exhaled nitric oxide measurement in adults and children. Respir Res. 2006; 7:67. | Article | PubMed Abstract | PubMed FullText

40. Rabinovitch $N$, Zhang $L$ and Gelfand EW. Urine leukotriene E4 levels are associated with decreased pulmonary function in children with persistent airway obstruction. J Allergy Clin Immunol. 2006; 118:635-40. | Article | PubMed

41. Baek HS, Cho J, Kim JH, Oh JW and Lee HB. Ratio of leukotriene e(4) to exhaled nitric oxide and the therapeutic response in children with exercise-induced bronchoconstriction. Allergy Asthma Immunol Res. 2013; 5:26-33. | Article | PubMed Abstract | PubMed FullText

42. Malli F, Papaioannou Al, Gourgoulianis KI and Daniil Z. The role of leptin in the respiratory system: an overview. Respir Res. 2010; 11:152. | Article | PubMed Abstract | PubMed FullText

43. Lugogo NL, Hollingsworth JW, Howell DL, Que LG, Francisco D, Church TD, Potts-Kant EN, Ingram JL, Wang Y, Jung SH and Kraft M. Alveolar macrophages from overweight/obese subjects with asthma demonstrate a proinflammatory phenotype. Am J Respir Crit Care Med. 2012; 186:404-11. | Article | PubMed Abstract | PubMed FullText

44. Cao J, Chen JH and Zhu SY. [Effects of leptin on airway inflammation and the expression of Th1/Th2 cytokines in asthmatic rats]. Zhonghua Jie He He Hu Xi Za Zhi. 2009; 32:171-6. | Article | PubMed

45. Sutherland TJ, Sears MR, McLachlan CR, Poulton R and Hancox RJ. Leptin, adiponectin, and asthma: findings from a population-based cohort study. Ann Allergy Asthma Immunol. 2009; 103:101-7. | Article | PubMed

46. Assad N, Qualls C, Smith LJ, Arynchyn A, Thyagarajan B, Schuyler M, Jacobs DR, Jr. and Sood A. Body mass index is a stronger predictor than the metabolic syndrome for future asthma in women. The longitudinal CARDIA study. Am J Respir Crit Care Med. 2013; 188:319-26. | Article | PubMed Abstract | PubMed FullText

47. Sood A, Qualls C, Schuyler M, Arynchyn A, Alvarado JH, Smith LJ and Jacobs DR, Jr. Adult-onset asthma becomes the dominant phenotype among women by age $\mathbf{4 0}$ years. the longitudinal CARDIA study. Ann Am Thorac Soc. 2013; 10:188-97. | Article | PubMed Abstract | PubMed FullText

48. Isidori AM, Strollo F, More M, Caprio M, Aversa A, Moretti C, Frajese G, Riondino $G$ and Fabbri A. Leptin and aging: correlation with endocrine changes in male and female healthy adult populations of different body weights. J Clin Endocrinol Metab. 2000; 85:1954-62. | Article | PubMed

49. Teodorescu M, Consens FB, Bria WF, Coffey MJ, McMorris MS, Weatherwax KJ, Palmisano J, Senger CM, Ye Y, Kalbfleisch JD and Chervin $\mathrm{RD}$. Predictors of habitual snoring and obstructive sleep apnea risk in patients with asthma. Chest. 2009; 135:1125-1132. | Article | PubMed

\section{Citation:}

Coffey MJ, Torretti B and Baptist A. Relationship between cysteinyl leukotrienes and nitric oxide in the pathogenesis of asthma in obesity. J Allergy Asthma. 2017; 4:1.

http://dx.doi.org/10.7243/2054-9873-4-1 